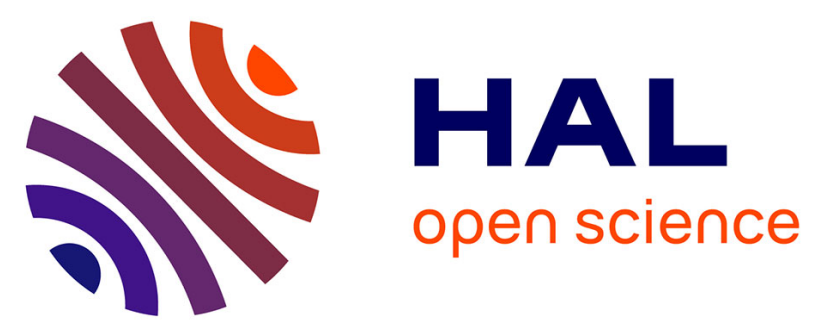

\title{
Characterization of cardinal vine shoot waste as new resource of lignocellulosic biomass and valorization into value-added chemical using Plackett-Burman and Box Behnken
}

\author{
Didaoui Amine, Abdeltif Amrane, Aksil Tounsia, Boubieb Naima
}

\section{To cite this version:}

Didaoui Amine, Abdeltif Amrane, Aksil Tounsia, Boubieb Naima. Characterization of cardinal vine shoot waste as new resource of lignocellulosic biomass and valorization into value-added chemical using Plackett-Burman and Box Behnken. Biomass Conversion and Biorefinery, 2021, 10.1007/s13399-02101717-1 . hal-03331007

\author{
HAL Id: hal-03331007 \\ https://hal.science/hal-03331007
}

Submitted on 15 Sep 2021

HAL is a multi-disciplinary open access archive for the deposit and dissemination of scientific research documents, whether they are published or not. The documents may come from teaching and research institutions in France or abroad, or from public or private research centers.
L'archive ouverte pluridisciplinaire HAL, est destinée au dépôt et à la diffusion de documents scientifiques de niveau recherche, publiés ou non, émanant des établissements d'enseignement et de recherche français ou étrangers, des laboratoires publics ou privés. 


\section{Characterization of Cardinal Vine Shoot Waste as new Resource of Lignocellulosic Biomass and Valorization}

into Value-added Chemical Using Plackett-Burman and Box Behnken

DIDAOUI Amine*1, AMRANE Abdeltif ${ }^{2}$, AKSIL Tounsia ${ }^{3}$, BOUBIEB Naima ${ }^{1}$

${ }^{1}$ Laboratory of Fibrous Polymers Treatment and Forming, Faculty of Technology, Department of Process Engineering, University M'hamed Bougara of Boumerdes, Algeria.

${ }^{2}$ Univ Rennes, Ecole Nationale supérieur de Chimie de Rennes, CNRS, ISCR - UMR 6226, F-35000 Rennes, France.

${ }^{3}$ Laboratory of Soft Technologies and Biodiversity, Faculty of Science, Department of Chemistry, University M'hamed Bougara of Boumerdes, Algeria.

*Corresponding author: a.didaoui@univ-boumerdes.dz.

\section{Abstract}

The objective of this work was to valorize a waste from cardinal vine shoot into a hydro-lysate rich in reducing sugars. Plackett-Burman design was considered to identify the significant factors while a Box Behnken design was considered to optimize the extraction in the following experimental conditions: $100{ }^{\circ} \mathrm{C}, 750 \mathrm{rpm}$, trifluoracetic acid $\left(\mathrm{CF}_{3} \mathrm{O}_{2} \mathrm{H}\right)$ concentration (TFA) in the range (1 - 10\%), during 20 to 180 min and considering the following solid-liquid (S/V) ratios (1:1, 3:1, 5:1). The optimal result was $2.53 \%$ in sugars equivalent to a yield of $50.64 \%$ per g of dry matter. Shoot vine waste was characterized by Attenuated Total Reflection-Fourier Transform Infrared Spectroscopy (ATR-FTIR), X-Ray Diffraction (XRD), Simultaneous Thermal Analysis (STA) and X-Ray Fluorescence (XRF). The chemical composition was $43.38 \%$ cellulose, $23.58 \%$ hemicellulose, 21.22\% lignin, 2.53\% ash, 5.82\% crude protein, $11.7 \%$ moisture and extractives ( $0.81 \%$ fat, $0.56 \%$ total sugars, $2.3 \%$ extractive (hexane-ethanol)). The promising potential of shoot vine waste to produce sugar and other added-value compounds was demonstrated.

Keywords: Hydrolysis; Extraction; Reducing sugar; Design of Experiments; Renewable Energy.

\section{Introduction}

Humans' progressive fuel consumption has driven people to find new energy resources either in the transport or other energy fields [1]. Fossil fuels are in finite amount and has causes severe environmental pollution [2, 3]. Renewable energy has therefore become more significant to achieve environment-healthy human and socioeconomic prosperity [4]. In this regard, research presents challenges in the development of green chemistry with the use of an important natural source of organic matter and accessible raw materials., to avoid ecosystem disruption [5, 6]. This requires the inclusion of various products with high added value, such as the energy source, solid fuel for combustion and biofuels, as well as biomaterials like bioplastic, road binder and dye dispersant in addition to other common chemicals like propanol, acetone, succinic acid, lactic acid, pesticides and others [7-9]. One of the renewable and sustainable resources is the lignocellulosic biomass [10]. 
Lignocellulosic waste materials are a promising source for various products; this is chosen in terms of overall cost, energy efficiency and environmental impact [11, 12]. Lignocellulosic biomass materials contain various polymers, such as polysaccharides (cellulose, hemicellulose), lignin along with polar and non-polar substances which are interwoven together $[13,14]$. The morphological structure of lignocellulosic biomass presents a complex structure, where the holocellulose and hemicellulose are closely linked to lignin, that hinders the depolymerisation of polysaccharides into monosaccharides [15]. Nowadays, agricultural wastes are excellent lignocellulosic feedstocks [16, 17]; biomass waste is considered interesting, since it is available in large amounts $[18,19]$. The grape is one of the major fruits to be cultivated by man and vine is an important plant crops in the world. Vine shoots represents the main waste fraction of the foot, representing roughly half of the vine mass and have been studied because they contain numerous polysaccharides including cellulose. The design of experiment for the variables optimization has a number of advantages $i$ ), it reduces the number of experiments, which results in the use of less material and reagent ii), it provides information on the interactions among the variables [20]. The Plackett Burman design is an essential tool in screening the effects of process variables. Further, it is frequently used to enhance the product yield, reduces the process variability and number of experiments, process time and overall cost [21-23]. The Response surface methodology (RSM) with Box Behnken design is a widely used mathematical optimization tool due to simultaneous analysis of interactions of several parameters with the minimum of experimental trials. Box Behnken design is a spherical type design which consists of central point and middle points of the edges of the cube circumscribed on the sphere [24, 25]. Grape production has increased extensively in recent decades. In Algeria, the region of Boumerdès is known for its wine culture and its table grapes, which represent $49 \%$ of its production. national production. The area devoted to vine plantations is about 13872 ha, divided into 10 varieties: Muscat, Italia, Chasselas, Victoria, Sultanine, wholesale Black, Red glob, Dattier, Sabelle and Cardinal. In general, the density of plantation is about 10000 foot per hectare producing $7 \mathrm{~kg}$ of vine waste biomass per foot, accounting for 971040 tons of biomass waste for the total area. To ensure the good harvest and fruiting, in winter the viticulturists focuses on the most important step which is the limitation of the excessive growth of vines. This generates waste rich in cellulose, namely a rich promoter for the extraction of sugars.

Accordingly, the purpose of the present work is to valorise the abundant lignocellulosic biomass from the waste of cardinal shoot vine and further to examine the chemical composition of the feedstock, including its physical and chemical characterizations. Otherwise, based on statistical techniques, the effect of different extraction parameters on the efficiency and recovery of hydro-lysate rich in reducing sugar without any chemical or 
biological pre-treatment of the vine shoot waste, was investigated. The extraction optimization was done in a two-step level. Plackett Burman design was used to screen the significant components, and then RSM based on the Box Behnken design was considered. The objective was to optimize the parameters of the screened factors, such as the extraction time, the concentration of trifluoroacetic acid (TFA) and the solid-liquid ratio to maximize the sugar extraction yield, as well as to reveal any possible interaction effect between the independent variables in a timely manner.

To the best of our knowledge, and according to the recent literature on lignocellulosic biomass from vine shoot waste, it has been used as natural resources of bioactive compounds such as production of lactic acid and lignin [26], resources of phenolic and antioxidant [27, 28], cellulose nanocrystals [29], oligosaccharides [30], biobutanol [31], bioethanol [32, 33] and bio-composite films [34].

\section{Materials and Methods}

\subsection{Raw Materials}

The vine shoot waste used in this work comes from cardinal grape variety. The samples were collected in the area of Bordj Menaiel (70 km East of Algiers) and thoroughly washed with distilled water, and dried for 20 days at room temperature in a ventilated dark room to protect the compounds from light oxidation. They were treated at $60^{\circ} \mathrm{C}$ for $24 \mathrm{~h}$, followed by mechanical treatment by a centrifugal miller (ground with an electrical grinder model MX-E1900- power $900 \mathrm{~W}$ Condor, Algeria), milled to a particle size of less than $1 \mathrm{~mm}$, and thereafter sieved $r$ to have a single and homogenized batch using handle stainless steel mesh sieve with aperture of $1 \mathrm{~mm}$. The size of the biomass after sieving was measured by laser granulometery particle size analyzer (Mastersizer 2000, Malvern Instruments). The feedstock was stored in airtight bags in a dark and dry place to be protected of moistures and light, until its further use. In the screening step, the feedstock was separated in two fractions. It was passed through two standard $125 \mu \mathrm{m}$ and $500 \mu \mathrm{m}$ sieves and stored in the same conditions. All chemicals used were purchased from Sigma-Aldrich (Algeria) and all solvents used were of analytical grade.

\subsection{Physical and chemical characterization of lignocellulosic biomass}

\subsubsection{Attenuated total reflection - Fourier transform infrared spectroscopy (ATR-FTIR).}

The ATR-FTIR analysis was performed on a ThermoScientific Nicolet IS 10 Model spectrophotometers (Thermo Electron Scientific Instruments IIC, Fitchburg, WI 53711, USA), equipped with ATR ThermoScientific Smart iTR module. The feedstock was milled to a particle size of less than $1 \mathrm{~mm}$. It was milled and sieved with handle 
stainless steel mesh with aperture $250 \mu \mathrm{m}$ and heated in oven-dried at $30{ }^{\circ} \mathrm{C}$ overnight to avoid the moisture absorption during milling and sieving; it was placed directly on the ATR crystal. The sample was characterized via ATR-FTIR spectroscopy in ATR mode with C/ZnSe crystal. The equipment worked in absorbance and transmission mode with a resolution of $2 \mathrm{~cm}^{-1}$ and a total of 40 scans was accumulated. The spectrum was obtained in the range $\left(4000-600 \mathrm{~cm}^{-1}\right)$.

\subsubsection{Biomass composition analysis}

In a previous study, the chemical composition of the lignocellulosic material from vine shoot waste was determined using the method prescribed in the Technical Association of Pulp and Paper Industry Standard Method (TAPPI) and the Association of Official Analytical Chemists (AOAC) Official Method. The weight fractions of the lignocellulose components were determined in triplicates.

Moisture and ash contents were estimated using standard protocol. Samples were heated (oven-dried, $105^{\circ} \mathrm{C}$, 24 h), (muffle furnace, $550^{\circ} \mathrm{C}, 5 \mathrm{~h}$ ), respectively. Tappi Standard T-211.om-02.2002 [35] and T-421.om-02.2002 [36].

Fat and extractives contents were extracted in a Soxhlet extractor (Diethyl ether $\left(\mathrm{CH}_{3}-\mathrm{O}-\mathrm{CH}_{3}\right.$, anhydrous, ACS Reagent, $\geq 99.9 \%$, Sigma-Aldrich), $80{ }^{\circ} \mathrm{C}, 50 \mathrm{~min}$ ), (Hexane $\mathrm{C}_{6} \mathrm{H}_{14}(\mathrm{~N}-$ Hexane, $99 \%$, AR, BIOCHEM Chemopharma); Ethanol ( $\mathrm{CH}_{3} \mathrm{CH}_{2} \mathrm{OH}$, Ethyl alcohol, pure, Sigma-Aldrich) ratio of 2:1 (V/V)), respectively. Tappi Standard T-204. cm.97 [37].

The lignin content was determined by extracting in $\mathrm{H}_{2} \mathrm{SO}_{4}$ (ACS, Reagent,95-98\%, Sigma-Aldrich), (72\% (V/V), at room temperature and constant stirring for $2 \mathrm{~h}$, then diluted to 3\% concentration (V/V) with distilled water. [38].

Holocellulose content: the biomass was milled into powder, sieved, dried in an oven-dried at $60{ }^{\circ} \mathrm{C}$ for $2 \mathrm{~h} .1 \mathrm{~g}$ of ground biomass was treated with $0.4 \mathrm{~g}$ of sodium chlorite ( $\mathrm{NaClO}_{2}$, puriss. p.a.80\% (RT), Sigma-Aldrich), 0.2 $\mathrm{ml}$ of $\mathrm{CH}_{3} \mathrm{COOH}$ (glacial, ACS reagent, $\geq 99.7 \%$, Sigma-Aldrich) and $32 \mathrm{ml}$ of distilled water, boiled in a water bath at $75^{\circ} \mathrm{C}$ for $1 \mathrm{~h}$. Every hour, $0.4 \mathrm{~g}$ of $\mathrm{NaClO}_{2}$, and $0.2 \mathrm{ml}$ of acetic acid were added until a whitish appearance was observed. The suspension was then cooled at room temperature, filtered under vacuum pump with filter crucible $N^{\circ} 4$ and washed with hot water repeatedly finally, it was dried in an oven at $105{ }^{\circ} \mathrm{C}$ until a constant weight was achieved. It was estimated by the measure of the mass loss. [39]. 
Content of $\alpha$-cellulose: $2 \mathrm{~g}$ of holocellulose were treated with $10 \mathrm{ml}$ of $\mathrm{NaOH}$ (ACS Reagent, $\geq 97 \%$, pellets, Sigma-Aldrich) at a concentration of 17.5\%. Then, it was mixed with class rod during 5 min., $5 \mathrm{~mL}$ of $\mathrm{NaOH}$ at the same concentration was added and mixed until all the total dissolution. The beaker was covered with parafilm to prevent evaporation, kept for $30 \mathrm{~min}$. at room temperature. $33 \mathrm{~mL}$ of distilled water was mixed and kept for $1 \mathrm{~h}$ filtered by using vacuum pump with filter crucible ( $\left.N^{\circ} 3\right)$. The residue was washed with $100 \mathrm{~mL}$ of $\mathrm{NaOH}$ solution (8.3\%) and rinsed with distilled water. $15 \mathrm{~mL}$ of acetic acid (10\%) was added and rinsed until reaching neutral pH ( 7). It was then rinsed with $250 \mathrm{~mL}$ of distilled water and dried in an oven-dried at $40{ }^{\circ} \mathrm{C}$ until a constant weight was reached. It was estimated by the measure of the mass loss [40].

The hemicellulose content of was calculated by the difference: content of holocellulose - content of $\alpha$-cellulose [40].

The crude protein content of vine shoot waste was calculated based on the $N$ amount, determined by the Kjeldahl method with appropriated factor 6.25 [41].

\subsection{3. $X$-ray diffraction (XRD)}

The XRD analysis was performed to distinguish the phases and to gain an overview of the morphology of the biomass and regularization of shear bands that form the structure of the polysaccharides [22]. The XRD pattern of shoot vines wastes were carried out at the $C u K \alpha$, radiation $\left(\lambda=1.54056 A^{\circ}\right)$. The test was run in an $X$-ray diffractometer (D8 Advance Bruker, Germany), operating in transmission mode, and working at a voltage of 40 $k V$ and $35 \mathrm{~mA}$ of filament emission. Further, diffractions intensities of $2 \theta$ peaks were measured in the range (05$40^{\circ}$ ) with step sizes of $0.04^{\circ}$ and scanning rate of $01 \% \min$.

The crystallinity index (CrI) was calculated from the height ratio between the height of the maximum interference $\left(I_{002}\right)$ and the intensity at $22.2^{\circ}$, referred as $\left(I_{a m}\right)[42]$. (Eq.1).

$\operatorname{CrI}=\left(I_{002}-I_{a m}\right) / I_{002} X 100$

\subsubsection{Simultaneous thermal analysis (STA)}

The thermal stability of the biomass was studied by STA analysis, combined TG-DSC techniques (thermogravimetry and differential scanning calorimetry) using an NETZSCH-Gerätebau GmbH analyzer (model STA 409 PC LUXX, Wittelsbacherstraße 42, D-95100 Selb-Bavaria, Germany). The aim of this analysis is to determine the thermal stability of the sample and to characterize and observe the transition phase and the interaction of the biomass as a function of temperature. The biomass was weighed in $\mathrm{AL}_{2} \mathrm{O}_{3} \mathrm{Crucible}$. A sample of 
$6.754 \mathrm{mg}$ was heated at $10^{\circ} \mathrm{C} \mathrm{min}-1$ under Ar flow at a flux of $10 \mathrm{ml} / \mathrm{min}$ as a carrier gas. Analysis was performed from 25 to $550^{\circ} \mathrm{C}$.

\subsubsection{X-ray fluorescence spectroscopy analysis (XRF)}

In the present study, the XRF analysis was carried out by using an XRF-1800 spectroscopy (Shimadzu, Japan) with vacuum medium to determine the mineralogical composition of the biomass. The latter was ground and sieved by a sieve of $0.050 \mathrm{~mm}$ porosity, shaped by the cold pressing process using a uniaxial press to obtain dense pellets.

\subsection{Design of experiments and statistical analysis}

The optimization of the process was based on the use of Plackett-Burman and Box Behnken designs with a view to saving energy and energy efficiency towards sustainable development with the aim of building a safe and healthy world based on the 12 principles of green chemistry.

\subsubsection{Data analysis}

The JMP software (version 13, SAS) was used to construct the Plackett-Burman and Box Behnken designs, as well as for regression analysis of the experimental data obtained.

\subsubsection{Plackett Burman design}

The P-B design was used to identify significant factors among the six factors considered in this study that influence and edit in sugar extraction yield.

The design was based on the following first order polynomial model (Eq.2).

$Y=\beta_{0}+\sum_{i=1}^{F} \beta_{i} X_{i}$

Where $Y$ is the dependent variable (response), namely the sugar extraction yield; .

$\beta_{0}$ the constant coefficient $=$ the model intercept $=$ the offset term.

$\beta_{i}$ the linear effect.

$F$ the number of the variable (input); in our case $F=6$.

$X_{i}$ the independent variables (factors).

In the present study, six factors (independent variables) or (input) including agitations speed $X_{1}$, concentrations of TFA acid $X_{2}$, temperature $X_{3}$, (solid/liquid) ratio $X_{4}$, particle size of powders $X_{5}$, extraction time $X_{6}$, were investigated to identify the significant factors for the sugar extraction yield. On the other hand, 12 run Plackett Burman design has evaluated the six factors. Each factor was evaluated at two levels -1 for the low level and +1 for the high level. The design is shown in table 1 and the given sugar extraction yields were the average of three trials. 


\section{Table 1}

\subsubsection{Box Behnken design}

The number of experiments was calculated according to the following equation (Eq.3).

$N=K^{2}+K+C_{p}$

Where $K$ is the factor number, $K=3$ in this study, $C p$ the replicate number of the center points $(C p=3)$ in the present study.

The multi-regression analysis of the data to fit a second-order polynomial equation (quadratic model) was carried out according to the following equation (Eq. 4.), which predicts the optimum conditions of the sugar extraction.

$\boldsymbol{Y}=\boldsymbol{\beta}_{0}+\sum_{i=1}^{F} \boldsymbol{\beta}_{i} \boldsymbol{X}_{i}+\sum \sum_{i=j-1}^{F} \boldsymbol{\beta}_{i j} \boldsymbol{X}_{i} \boldsymbol{X}_{J}+\sum_{i=1}^{F} \boldsymbol{\beta}_{i i} \boldsymbol{X}_{i}^{2}$

Where $Y$ is the dependent variable (response), namely the sugar extraction yield.

$\beta_{0}=$ the constant coefficient $=$ was the model intercept $=$ was the offset term.

$\beta_{i}=$ the linear effect; $\beta_{i i}=$ was the quadratic effect; $\beta_{i j}=$ was the interaction effect.

$F=$ the number of the variable (input); Xi and $X_{j}$ are the independent variables.

In this study, a Box Behnken design with three factors and three levels was used to optimize the parameters of the screened factors, such as the TFA concentration, $X_{1}$, the (solid / liquid) radio, $X_{2}$, the extraction time, $X_{3}$, to maximize the sugar extraction yield, leading to 15 runs. Each factor was evaluated at three levels (-1) for the low level and (0) middle level or central level and (+1) for high level. The design is shown in table 2 and the given sugar extraction yields were the average of three trials. Experiments were carried out in a random order to avoid any bias to reduce the outcomes of unpredicted variability in the responses due to irrelevant factors.

Table 2

\subsection{Extraction and analysis of Sugars}

The sugar extraction was carried out in $500 \mathrm{~mL}$ flat bottom Bicol containing a diluted acid solution TFA $\left(\mathrm{CF}_{3} \mathrm{CO}_{2} \mathrm{H}, \mathrm{BIOCHEM}\right.$ Chemopharma) with a biomass associated with a temperature controller RDT (Resistance Temperature Detector) temperature sensor (Pt 100) at the desired set-point subjected to a digital hot plat equipped with a digital stirrer under reflux using a water condenser $(30 \mathrm{~cm})$. The objective was the liquid steam equilibrium to prevent loss of mass by evaporation. This dilute acid solution $\left(\mathrm{CF}_{3} \mathrm{CO}_{2} \mathrm{H}\right)$ was used due to 
various reasons such as the sugars which generally remain stable during hydrolysis, efficiency, and easily removed from hydrolysates (Volatile). After extraction, the hydrolysate was cooled with water, and filtered under Büchner using a vacuum pump to remove impurities from the biomass. It was neutralized with $\mathrm{NaOH}(1 \mathrm{~mol} / \mathrm{L})$ until a pH of 5.10. delignification and detoxification was performed with M3 g per liter of charcoal powder [16, 43], filtered under vacuum with filter crucible $N^{\circ} 3$. The hydro-lysate was vigorously centrifuged (3000 rpm, 10 min.), filtered through a funnel, splashed with $N_{2}$ gas, sterilized in an autoclave at $121{ }^{\circ} \mathrm{C}$ for 20 min. and finally cooled to $4^{\circ} \mathrm{C}$. The sugars were evaluated by the dinitro salicylic acid (DNS) method. $1 \mathrm{~mL}$ of hydro-lysate was mixed with $1.5 \mathrm{~mL}$ of DNS reagent, boiled in a water bath at $100{ }^{\circ} \mathrm{C}$ for $5 \mathrm{~min}$. The obtained sample was cooled with water, to which $7.5 \mathrm{ml}$ of distilled water was added. The absorbance was measured at $530 \mathrm{~nm}$ [44].

\section{Results and Discussion}

\subsection{Particle size analysis using laser granulometry}

Fig 1 show the particle size of the all samples where the size of the flour of the vine shoot wood lies between 7 and $830 \mu \mathrm{m}$, indicating a very fine biomass. Such range of sizes should drastically reduce the crystallinity of cellulose, thus improving the depolymerization of the cellulose by acid hydrolysis leading to a hydro-lysate rich in sugars. The curve A (Fig. 1) represents the particle size distribution of shoot vine waste as a function of its amount present in the lignocellulosic biomass after grinding. The large amount obtained by the grinder was between 120 and $830 \mu \mathrm{m}$, which represents a very fine biomass. Lignocellulosic biomass was sieved and separated in two samples and used in the screening and optimization processes. The red color in this figure shows the amount of lignocellulosic biomass with particle sizes less than $125 \mu \mathrm{m}$.

\section{Figure 1}

According to Fig. 1, the sample contains a large part of particles with size in the range (7 - $100 \mu \mathrm{m})$. The black line indicates the amount of lignocellulosic biomass with particle size less than $500 \mu \mathrm{m}$. A large amount of the particles have sizes between 80 to $500 \mu \mathrm{m}$. Moreover, the amount of lignocellulosic biomass which must undergo further grinding corresponds to the blue line.

\subsubsection{ATR-FTIR analysis}

The ATR-FTIR spectroscopy was used to determine the molecular structure present in the vine shoots waste by identifying the functional groups; the corresponding spectra are illustrated in Figure 2. 
Figure 2

The wide band observed in the region $\left(3700 \mathrm{~cm}^{-1}-3000 \mathrm{~cm}^{-1}\right)$ is commonly attributed to the $\mathrm{O}-\mathrm{H}$ stretching vibrations; furthermore, this band could also be associated to the structure of cellulose molecules as well as aromatic and aliphatic hydroxyl groups. In addition, the $\mathrm{O}-\mathrm{H}$ bending which appears at the same band which characterizes the adsorbed water, accounting for the hydrophilic tendency of the fibres; while the peak position at $2930 \mathrm{~cm}^{-1}$ indicates the $\mathrm{C}-\mathrm{H}$ stretching vibration [29, 45]. On the other hand, the broad band at $1036 \mathrm{~cm}^{-1} \mathrm{can}^{-}$ be attributed to the cellulose, present in the spectrum with high intensity, associated with $\mathrm{C}$-O-C asymmetric bridge stretching [26, 46]. The small band centred at $1232 \mathrm{~cm}^{-1}$ responds to the $C-O$ stretching, and is characteristic of the hemicellulosic and lignin fractions. The small peak at $1500 \mathrm{~cm}^{-1}$ can be due to proteins [47] while that at 1731 $\mathrm{Cm}^{-1}$ is related to the carbonyl ester group $C=O$ bond stretching present in hemicellulose [48], the peak at 1611 $\mathrm{cm}^{-1}$ attributed the stretching of $\mathrm{C}=\mathrm{O}$ group of hemicellulose contents [49].

\subsubsection{Biomass composition analysis}

The biomass composition is given in Table 3. The sample was put in an oven-dried at $40{ }^{\circ} \mathrm{C}$, cooled in a desiccator so that the biomass does not absorb moisture. The moisture content is one of the preliminary signs of the rate of cellulose because of its adsorption factor. The extractable level represents the soluble materials in organic solvents. In our case, it is a mixture of ethanol / hexane, and hence the extracted compounds are the following: flavonoids, terpenes, stilbenes, and tannins, which give the color and the smell of wood.

According to the chemical characterization of the biomass, the holocellulose content was 66.96\% of the dry weight. It is the addition of the cellulose and hemicellulose fractions, showing the richness of the biomass in cellulose and hence in reducing sugars and an average level of lignin, which is in favor of a detoxification with the charcoal powder. It can also be noted a richness of the biomass in protein, with a yield of 5.62\%. The reducing sugars obtained from lignocellulosic biomass are usually used in the fermentation under aerobic conditions using microorganisms for the biofuels production, these micro-organisms need a source of carbon (reducing sugar), nitrogen (protein), vitamins and minerals for their growth. This composition of Cardinal vine shoot waste can lead to produce the bioethanol as fuel for the transport sector.

The Klason lignin content was comparable to that of some agricultural residues, such as palm kernel shells $45 \%$, palm mesocarp fiber 32\%, Arecanut husk 31.6\%, eucalyptus 27\%, rice straw $26.30 \%$, Douglas fir $25.3 \%$, rice husk 23\%, bagasse $22.8 \%$ [15, 26, 50, 51]. 
The lignocellulosic biomass from cardinal vine shoot waste was compared with those reported in the literature, the sample is the vine shoot waste with grape variety Hondarridi Zuri supplied by the local winery Aldako Bodega. S.L. (Oiartzun, Bsque Country, Spain) characterized by a particle size of $\sim 0.4 \mathrm{~cm}, 27 \%$ hemicellulose, $26 \%$ of ash, 3.1\% of extractable. To our knowledge, the chemical composition of this biomass is different with our lignocellulosic biomass due to the nature of the soil, meteorological conditions and also the nature of the variety [26].

\section{Table 3}

\subsection{3. $X$-ray diffraction analysis $(X R D)$}

The XRD analysis of the shoot vine waste is displayed in Fig. 3, and the pattern is based on the literature data and the use of International Centre for Diffraction Data ICDD.

\section{Figure 3}

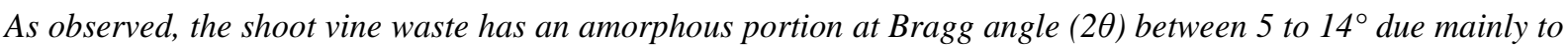
lignin and hemicellulose, as well as to other compounds, which give a disordered structure, rice to border and less defined peak, respectively. Further, shoot vines waste has peaks related to the crystallographic plans of cellulose in accordance with the $2 \theta$ angle at $15^{\circ}, 22.2^{\circ}, 26.5^{\circ}$ and $34.6^{\circ}$, which can be ascribed to the crystallographic planes (101), (002), (002) and (040), respectively, due to the perfect regular arrangement of the molecules in an equatorial plane, giving its rigidity [52]. This gives information on the presence of alpha-cellulose, a regular periodic structure, which gives, responsible of the crystallinity of the biomass [53].

The CrI of the non-treated lignocellulosic biomass from cardinal vine shoot waste (33.59\%) with a particle size less than $1 \mathrm{~mm}$, was compared with another sample of vine shoot waste (CrI in the raw state without pretreatment was $65.29 \%$, with hydrothermally pretreated was $43.60 \%$, particle size was $0.4 \mathrm{~cm}$ ). The same sample was compared with the chemical composition section), and it can be concluded that the lignocellulosic biomass from Cardinal vine shoot waste is better than Hondarridi Zuri shoot vine waste supplied by a local winery Aldako Bodega. S.L. (Oiartzun, Bsque Country, Spain) in terms of crystallinity index. [26]. 


\subsubsection{Simultaneous thermal analysis (STA)}

In the present study, simultaneous thermal analysis was used to examine the thermal decomposition of shoot vines waste in the range $\left(25-550^{\circ} \mathrm{C}\right)$. Analysis of the TG / DSC spectra shows four stages (Fig.4).

\section{Figure 4}

The first one at $100^{\circ} \mathrm{C}$; a small and endothermic band corresponding to weight loss accounting for 5\% is observed at $53{ }^{\circ} \mathrm{C}$ ascribed to the loss of absorbed water by the cellulosic fibers and represents the evaporation of the moisture adsorbed into the sample [54]. In the second stage, the thermal degradation begins at $\sim 240{ }^{\circ} \mathrm{C}$ and represents the degradation of extractible, lipid, protein and other components. In addition, the first exothermic peak and the maximum rates of weight loss are observed from $250{ }^{\circ} \mathrm{C}$ to $380{ }^{\circ} \mathrm{C}$ corresponding to the decomposition of polymers (cellulose, hemicellulose and lignin) to generate volatile compounds [55]. This means that the glyosidic bond chains are broken down, leading to the dissolution of the amorphous phase. In the third stage, between 400 and $500^{\circ} \mathrm{C}$, a sharp exothermic peak occurs and a major peak is observed from 400 to $480^{\circ} \mathrm{C}$ corresponding to the total decomposition of the cellulose and to the generation of volatile compounds, indicating the destruction and total carbonization of the sample.; The remaining residues above $500{ }^{\circ} \mathrm{C}$ in the end product were mainly ash derived from the biomass.

\subsubsection{X-ray fluorescence spectroscopy}

According to the results of the fluorescence (Table 3), the lignocellulosic biomass has an overall mineral composition of $2.5 \%$, which constitute the nutrients of cell growth, such as calcium in the form of CaO which represents a major component of the biomass, namely $61.5 \%$ of the minerals. It has an importance in the plant physiology and a role in the cohesion of cell walls. Phosphorus pentoxide $\left(\mathrm{P}_{2} \mathrm{O}_{5}\right)$ is a phosphate fertilizer, crucial for the roots and shoot growth of the vine; potash fertilizer is added in the form of $\mathrm{K}_{2} \mathrm{O}$ as a nutrient for the cell development. The presence of silica is a sign that the biomass was not well irrigated; silica is adsorbed by the plant in the form of silicic acid.

\subsection{Design of experiments}

\subsubsection{Screening of the significant factors using Plackett-Burman design}

In this study, six variables were selected for the screening using the Plackett-Burman design. The experimental conditions to be verified were selected on the basis of the highest desirability. In total, 12 experimental runs for 
reducing sugar production with combination with the two levels of each variable were performed as shown in Table 4.

\section{Table 4}

The impact of the six factors considered in this study on the reducing sugar yield from shoot vine waste was statistically analyzed. The aim of this screening is to evaluate the factors which have a significant effect on reducing sugar yield for further optimization study using Box Behnken design. Reducing sugar yields from the shoot vine waste range from 0.01 to $1 \mathrm{~g} / \mathrm{l}$; it is a wide variation in the sugar extraction (Table 4). The coefficient of determination $\left(R^{2}\right)$ of the Plackett-Burman model is 0.90 while the adjusted $\left(R^{2}\right)$ is 0.81 . This shows that the predicted $\left(R^{2}\right)$ values are close to the adjusted $\left(R^{2}\right)$, indicating the accuracy of the model. The analysis of variance of Plackett-Burman model are given in Table 5.

\section{Table 5}

The regression model (ANOVA) is highly significant to represent the dependence of the reducing sugar yield on the components studied. If the P-value is $<0.05$ the respective terms were said to be significant. On the other side, P-value greater than 0.05 indicates insignificant terms. In our case, three factors were considered as the most significant factors namely the liquid/solid ratio with P-value 0.01107 (very low), the temperature with P-value 0.01549 and the TFA concentration with P-value 0.02785. While the three others, namely the agitation speed (rpm), the extraction time and the particle size showed insignificant effects on the reducing sugar yield (Table 6).

Table 6

The model of the first-order polynomial equation was applied to determine the relationship between the factors and the response as shown in the following equations:

$Y=($ sugar extraction yield $)=0.4494+0.0756 X_{1}+0.1084 X_{2}+0.1273 X_{3}+0.3123 X_{4}+0.0479 X_{5}+0.0705 X_{6}$ (Table 7)

Table 7 
The optimal reaction in the experimental screening was achieved when the (solid/liquid) ratio was set at 5, temperature at $100{ }^{\circ} \mathrm{C}$, agitation speed at $750 \mathrm{rpm}$, TFA concentration 10\%, granular size 500 um and an extraction time of 180 min. (Table 4).

\subsubsection{Optimization using Box Behnken design}

The most puzzling part of this study is the optimization process for obtaining the maximum of reducing sugar. The Box Behnken design is used to optimize the number of experiments to be executed by determining the feasible interactions between the parameters studied and their effects on the reducing sugar yield from the shoot vine waste. In total, fifteen experimental runs and three central points were designed and performed according to the conditions, which were applied in each run. (Table 7). The optimization of the experimental conditions were determined by setting targets for targeting the desire for responses. These conditions were based on the PlackettBurman design, summarized as follows: agitation speed and particle size remained unchanged, namely 750 rpm and $125 \mu \mathrm{m}$ respectively, according to the screening plan, which seem to be insignificant these-(Table 5). Although, the temperature is a significant factor, it was fixed at $100{ }^{\circ} \mathrm{C}$, due to our equipment and was the maximum allowed on our assembly. Furthermore, exposure time was variable. The significant factors were optimized based on the objective of having the less corrosive environment and rich in reducing sugars. Experimental results and those of the optimization according to the Box Behnken design are illustrated in Table 7. The results of the Box Behnken design showed that the best amount of extraction was obtained in the experimental run $N^{\circ}: 8$ giving $2.53 \mathrm{~g} / \mathrm{L}$ of reducing sugar, while the lowest total sugar release $(50 \mathrm{mg} / \mathrm{L})$ was achieved in run No:11 (Table 7). In the optimization study, the yield of reducing sugar in vine shoot waste has increased by $150 \%$ compared to screening. The highest amounts of extraction were $2.53 \mathrm{~g} / \mathrm{L}$ (Table 7) and $1.0 \mathrm{~g} / \mathrm{L}$ (Table 4) in the optimization and screening, respectively. The second-order polynomial model was applied to determine the relationship between the yield of reducing sugar and the tested parameters.

$Y=0.7188+0.0775 X_{1}+0.4601 X_{2}+0.3701 X_{3}+00.0526 X_{1} X_{2}-0.0709 X_{1} X_{3}+0.4499 X_{2} X_{3}-0.4147 X_{1}^{2}+$

$0.1467 X_{2}^{2}+0.1717 X_{3}^{2}$. (Table 8).

Table 8

Where the coefficients for the linear, quadratic and interaction effects of the variables coded as $X_{1}$ the concentration of TFA acid, $X_{2}$ the (solid/liquid) ratio and $X_{3}$ the extraction time on the reducing sugar yield. The positive sign of the coefficients in the equation indicates a synergistic effect, whereas a negative sign symbolizes 
an antagonistic effect on the response. In this study of Box Behnken design, the predicted values are in agreement with the experimental data (Table 7). The $\left(R^{2}\right)$ value close to 1 indicates that the model is the best fit and denotes a better correlation between observed and predicted values. The coefficient of determination $\left(R^{2}\right)$ of the Box Behnken model was 0.96 and the adjusted $\left(R^{2}\right)$ 0.89. This shows that the predicted $\left(R^{2}\right)$ values were close to the adjusted $\left(R^{2}\right)$, indicating the accuracy of the model. The ANOVA results for the Quadratic model are given in Table 9. The P-value $<5 \%$ indicate that the model terms are significant at 95\% confidence level. The P-value and F-value were applied to determine the significant of the coefficient and the interaction strength of combined factors. The factors are significant for low P-value and high F-value. This analysis showed that the overall model was significant $(F$-value $=13.5177)$, with very low probability value $(P$-value $=0.0052)($ Table 9$)$. In addition, the interaction effect between the (solid/liquid) ratio and the extraction time $\left(X_{2} * X_{3}\right)$ was significant (Table 9), as well as between $\left(X_{1} * X_{2}\right)$, concentration of TFA acid and (solid/liquid) ratio, with P-value $=0.0056$. Thus, $\left(X_{1}\right.$ $\left.* X_{3}\right)$ Concentration of TFA acid and Time extraction were insignificant at 95\% confidence level, with $(P$-value $=$ $0.6105)$ and $(P$-value $=0.4973)$, respectively $\left(\right.$ Table 9). On the other hand, linear effect $\left(X_{2}\right),\left(X_{3}\right)$ and quadratic effect $\left(X_{1}^{2}\right)$ were identified as significant which are also evident from (P value $\left.=0.0011\right)$, $(P$ value $=0.0019)$ and $(P$ value $=0.0092)$, respectively. However, all the others were insignificant $(P$-value $>0.05)($ Table 9$)$.

The three- dimensional response surface plots (Fig. 5) shows the interaction effect between various parameters and used to predict the optimum levels of each factor to obtain the maximum response. Fig (5a) shows the interaction effect of extraction time and (solid/liquid) ratio on the reducing sugar yield. Both the extraction time and (solid/liquid) ratio have a positive impact on the reducing sugar yield, when they increase from their middle to higher level. The regular and spherical shape of the contour plot confirmed a significant interaction effect on the reducing sugar yield, in agreement with the P-value= 0.0056 (Table 9). However, no significant change in the reducing sugar yield was observed due to change in concentration of TFA acid; Thus, there was no interaction between concentration of TFA acid and extraction time on the reducing sugar yield (Fig. 5b), in accordance with the P-value, 0.4973 (Table 9) and Fig(5c). In addition, there is no interaction between the TFA concentration and the (solid/liquid) ratio on the reducing sugar yield (Fig.5c), in accordance with the P-value, 0.6105 (Table 9).

\section{Table 9}

\section{Figure 5}

The lack of fit is the variation of the data around the fitted model. The probability value of the lack of fit was insignificant, which illustrated that the quadratic model was valid for this study, as well as relatively to the pure 
error. Optimum conditions according to the Box Behnken model were therefore: temperature $100{ }^{\circ} \mathrm{C}$, agitation speed 750 rpm, (V/V) TFA acid 5.5\%, particle seize $125 \mu \mathrm{m}$, (liquid-solid) ratio (5g/100 mL) and extraction time 180 min, leading to a maximum reducing sugar yield of $2.53 \mathrm{~g} / \mathrm{L}$.

\section{Conclusions}

The primary goal of this study was the valorization of the lignocellulosic biomass from cardinal vine shoot waste into added-value compounds and to achieve maximum reducing sugars amount. Additionally, the results obtained from physical and chemical characterizations demonstrated that cardinal vine shoot waste is an excellent source of bioactive compounds and can be used as potential feedstock to produce biochemical, not only in Algeria, but worldwide. The Plackett-Burman and Box Behnken designs were effective approaches to screen and to optimize the extraction parameters of reducing sugars to obtain maximum yield. In the screening step, the Plackett-Burman design was employed to determine important factors influencing the sugar extraction, six factors were selected (particle size, concentration, temperature, (solid-liquid) ratio, extraction time and agitation speed. Among these factors, the Plackett-Burman design allowed to identify the temperature, concentration and (solid-liquid) ratio as the significant factors influencing the sugar extraction. The optimal conditions in the screening were as follows (500 $\mu \mathrm{m}, 10 \%$ (V/V), $100 \mathrm{C}^{\circ}, 5 \mathrm{~g} / 100 \mathrm{ml}, 180 \mathrm{~min}$ and $750 \mathrm{rpm}$ ). In the optimization step, the Box Behnken design was successfully applied to optimize the process conditions and to evaluate the effect of the selected variables in the screening step, three factors were optimized (extraction time, concentration and (solid-liquid) ratio). In this step, the extraction of the reducing sugar was increased from 1 to $2.53 \mathrm{~g} / \mathrm{L}$, with a yield of $150 \%$. The optimized conditions according to the Box Behnken model were the following: (125 $\mu \mathrm{m}, 5.5 \%$ (V/V), $100 \mathrm{C}^{o}, 5 \mathrm{~g} / 100 \mathrm{~mL}$, $180 \mathrm{~min}$ and $750 \mathrm{rpm})$. The polynomial model fitted accurately the experimental data and optimum conditions; and hence the model was therefore experimentally validated. The chemical composition of the cardinal vine shoot waste was as follows (43.38\% cellulose, 23.58\% hemicellulose, 21.22\% lignin, 2.53\% ash, 5.82\% crude protein, 11.7\% moisture and extractives (0.81\% fat, $0.56 \%$ total sugars, $2.3 \%$ extractive (hexane-ethanol)).

\section{Declarations of competing interest}

This study did not receive any specific grant from funding agencies in the public, commercial or not-for-profit sectors.

\section{CRediT Authorship contribution statement}


DIDAOUI Amine: Writing-Original Draft, Methodology, Conceptualization, Software, Data Curation,

Validation, Investigation, Formal analysis.

AMRANE Abdeltif: Conceptualization, Visualization, Supervision, Writing-Review \& editing.

AKSIL Tounsia: Software, Validation, Supervision, Writing-Review \& editing, Project administration.

BOUDIEB Naima: Methodology, Visualization, Supervision, Writing-Original Draft, Project administration.

\section{References}

1. Patel M, Patel HM, Dave S (2020) Determination of bioethanol production potential from lignocellulosic biomass using novel Cel-5m isolated from cow rumen metagenome. International Journal of Biological Macromolecules 153:1099-1106. https://doi.org/10.1016/j.ijbiomac.2019.10.240

2. Mishra RK, Mohanty K (2018) Characterization of non-edible lignocellulosic biomass in terms of their candidacy towards alternative renewable fuels. Biomass Conv Bioref 8:799-812. https://doi.org/10.1007/s13399-018-0332-8

3. Indira D, Jayabalan R (2020) Saccharification of lignocellulosic biomass using seawater and halotolerant cellulase with potential application in second-generation bioethanol production. Biomass Conv Bioref 10:639-650. https://doi.org/10.1007/s13399-019-00468-4

4. Rocha-Meneses L, Raud M, Orupõld K, Kikas T (2019) Potential of bioethanol production waste for methane recovery. Energy 173:133-139. https://doi.org/10.1016/j.energy.2019.02.073

5. C. IP, R. S (2020) Characterization of a new natural cellulosic fiber extracted from Derris scandens stem. International Journal of Biological Macromolecules 165:2303-2313. https://doi.org/10.1016/j.ijbiomac.2020.10.086

6. Sabarinathan P, Rajkumar K, Annamalai VE, Vishal K (2020) Characterization on chemical and mechanical properties of silane treated fish tail palm fibres. International Journal of Biological Macromolecules 163:2457-2464. https://doi.org/10.1016/j.ijbiomac.2020.09.159

7. Messaoudi Y, Smichi N, Bouachir F, Gargouri M (2019) Fractionation and Biotransformation of Lignocelluloses-Based Wastes for Bioethanol, Xylose and Vanillin Production. Waste Biomass Valor 10:357-367. https://doi.org/10.1007/s12649-017-0062-3

8. Ehman NV, Lourenço AF, McDonagh BH, et al (2020) Influence of initial chemical composition and characteristics of pulps on the production and properties of lignocellulosic nanofibers. International Journal of Biological Macromolecules 143:453-461. https://doi.org/10.1016/j.ijbiomac.2019.10.165

9. Nuchdang S, Thongtus V, Khemkhao M, et al (2020) Enhanced production of reducing sugars from paragrass using microwave-assisted alkaline pretreatment. Biomass Conv Bioref. https://doi.org/10.1007/s13399-020-00624-1

10. Sewsynker-Sukai Y, Gueguim Kana EB (2018) Simultaneous saccharification and bioethanol production from corn cobs: Process optimization and kinetic studies. Bioresource Technology 262:32-41. https://doi.org/10.1016/j.biortech.2018.04.056

11. Dutra ED, Santos FA, Alencar BRA, et al (2018) Alkaline hydrogen peroxide pretreatment of lignocellulosic biomass: status and perspectives. Biomass Conv Bioref 8:225-234. https://doi.org/10.1007/s13399-017-0277-3

12. De S, Mishra S, Poonguzhali E, et al (2020) Fractionation and characterization of lignin from waste rice straw: Biomass surface chemical composition analysis. International Journal of Biological Macromolecules 145:795-803. https://doi.org/10.1016/j.ijbiomac.2019.10.068 
13. Raja Sathendra E, Baskar G, Praveenkumar R, Gnansounou E (2019) Bioethanol production from palm wood using Trichoderma reesei and Kluveromyces marxianus. Bioresource Technology 271:345-352. https://doi.org/10.1016/j.biortech.2018.09.134

14. Azzouz Z, Bettache A, Djinni I, et al (2020) Biotechnological production and statistical optimization of fungal xylanase by bioconversion of the lignocellulosic biomass residues in solid-state fermentation. Biomass Conv Bioref. https://doi.org/10.1007/s13399-020-01018-z

15. Cunha M, Romaní A, Carvalho M, Domingues L (2018) Boosting bioethanol production from Eucalyptus wood by whey incorporation. Bioresource Technology 250:256-264.

https://doi.org/10.1016/j.biortech.2017.11.023

16. Sarawan C, Suinyuy TN, Sewsynker-Sukai Y, Gueguim Kana EB (2019) Optimized activated charcoal detoxification of acid-pretreated lignocellulosic substrate and assessment for bioethanol production. Bioresource Technology 286:121403. https://doi.org/10.1016/j.biortech.2019.121403

17. Nguyen TVT, Unpaprom Y, Manmai N, et al (2020) Impact and significance of pretreatment on the fermentable sugar production from low-grade longan fruit wastes for bioethanol production. Biomass Conv Bioref. https://doi.org/10.1007/s13399-020-00977-7

18. Harini K, Ramya K, Sukumar M (2018) Extraction of nano cellulose fibers from the banana peel and bract for production of acetyl and lauroyl cellulose. Carbohydrate Polymers 201:329-339.

https://doi.org/10.1016/j.carbpol.2018.08.081

19. Ibarra-Díaz N, Castañón-Rodríguez JF, Gómez-Rodríguez J, Aguilar-Uscanga MG (2020) Optimization of peroxide-alkaline pretreatment and enzymatic hydrolysis of barley straw (Hordeum vulgare L.) to produce fermentable sugars using a Box-Behnken design. Biomass Conv Bioref. https://doi.org/10.1007/s13399020-00853-4

20. Manmai N, Unpaprom Y, Ramaraj R (2020) Bioethanol production from sunflower stalk: application of chemical and biological pretreatments by response surface methodology (RSM). Biomass Conv Bioref. https://doi.org/10.1007/s13399-020-00602-7

21. Wang B, Song Q, Zhao F, et al (2019) Production optimization, partial characterization and properties of an exopolysaccharide from Lactobacillus sakei L3. International Journal of Biological Macromolecules 141:21-28. https://doi.org/10.1016/j.ijbiomac.2019.08.241

22. Saleh AK, Soliman NA, Farrag AA, et al (2020) Statistical optimization and characterization of a biocellulose produced by local Egyptian isolate Komagataeibacter hansenii AS.5. International Journal of Biological Macromolecules 144:198-207. https://doi.org/10.1016/j.ijbiomac.2019.12.103

23. Silva TP, Ferreira AN, de Albuquerque FS, et al (2021) Box-Behnken experimental design for the optimization of enzymatic saccharification of wheat bran. Biomass Conv Bioref. https://doi.org/10.1007/s13399-021-01378-0

24. John I, Pola J, Appusamy A (2019) Optimization of Ultrasonic Assisted Saccharification of Sweet Lime Peel for Bioethanol Production Using Box-Behnken Method. Waste Biomass Valor 10:441-453. https://doi.org/10.1007/s12649-017-0072-1

25. Chan YT, Tan MC, Chin NL (2019) Application of Box-Behnken design in optimization of ultrasound effect on apple pectin as sugar replacer. LWT 115:108449. https://doi.org/10.1016/j.lwt.2019.108449

26. Dávila I, Remón J, Gullón P, et al (2019) Production and characterization of lignin and cellulose fractions obtained from pretreated vine shoots by microwave assisted alkali treatment. Bioresource Technology 289:121726. https://doi.org/10.1016/j.biortech.2019.121726

27. Moreira MM, Barroso MF, Porto JV, et al (2018) Potential of Portuguese vine shoot wastes as natural resources of bioactive compounds. Science of The Total Environment 634:831-842. https://doi.org/10.1016/j.scitotenv.2018.04.035 
28. Troilo M, Difonzo G, Paradiso VM, et al (2021) Bioactive Compounds from Vine Shoots, Grape Stalks, and Wine Lees: Their Potential Use in Agro-Food Chains. Foods 10:342.

https://doi.org/10.3390/foods10020342

29. El Achaby M, El Miri N, Hannache H, et al (2018) Production of cellulose nanocrystals from vine shoots and their use for the development of nanocomposite materials. International Journal of Biological Macromolecules 117:592-600. https://doi.org/10.1016/j.ijbiomac.2018.05.201

30. Dávila I, Gullón P, Labidi J (2021) Influence of the heating mechanism during the aqueous processing of vine shoots for the obtaining of hemicellulosic oligosaccharides. Waste Management 120:146-155. https://doi.org/10.1016/j.wasman.2020.11.014

31. Garita-Cambronero J, Paniagua-García AI, Hijosa-Valserohij M, Díez-Antolínez R (2021) Biobutanol production from pruned vine shoots. Renewable Energy S0960148121007758. https://doi.org/10.1016/j.renene.2021.05.093

32. Senila L, Kovacs E, Scurtu DA, et al (2020) Bioethanol Production from Vineyard Waste by Autohydrolysis Pretreatment and Chlorite Delignification via Simultaneous Saccharification and Fermentation. Molecules 25:2606. https://doi.org/10.3390/molecules25112606

33. Pachón ER, Mandade P, Gnansounou E (2020) Conversion of vine shoots into bioethanol and chemicals: Prospective LCA of biorefinery concept. Bioresource Technology 303:122946. https://doi.org/10.1016/j.biortech.2020.122946

34. Benito-González I, Jaén-Cano CM, López-Rubio A, et al (2020) Valorisation of vine shoots for the development of cellulose-based biocomposite films with improved performance and bioactivity. International Journal of Biological Macromolecules 165:1540-1551. https://doi.org/10.1016/j.ijbiomac.2020.09.240

35. Moisture in pulp, paper and paperboard, Test Method TAPPI/ANSI T 412 om-16

36. T. Tappi, Ash in Wood, Pulp, Paper and Paperboard: Combustion at 525 C, TAPPI Test Methods T 211, 1993.

37. Solvent Extractives of Wood and Pulp, Test Method T 204 cm-17

38. Acid-insoluble lignin in wood and pulp, Test Method T 222 om-15

39. Candelier K Caractérisation des transformations physico-chimiques intervenant lors de la thermodégradation du bois. Influence de l'intensité de traitement, de l'essence et de l'atmosphère. 141

40. Alpha-, beta- and gamma-cellulose in pulp, Test Method T 203 cm-09

41. Bicsak RC, Collaborators:, Boles R, et al (1993) Comparison of Kjeldahl Method for Determination of Crude Protein in Cereal Grains and Oilseeds with Generic Combustion Method: Collaborative Study. Journal of AOAC INTERNATIONAL 76:780-786. https://doi.org/10.1093/jaoac/76.4.780

42. Nam S, French AD, Condon BD, Concha M (2016) Segal crystallinity index revisited by the simulation of X-ray diffraction patterns of cotton cellulose I $\beta$ and cellulose II. Carbohydrate Polymers 135:1-9. https://doi.org/10.1016/j.carbpol.2015.08.035

43. Thangavelu SK, Rajkumar T, Pandi DK, et al (2019) Microwave assisted acid hydrolysis for bioethanol fuel production from sago pith waste. Waste Management 86:80-86.

https://doi.org/10.1016/j.wasman.2019.01.035

44. Miller GL (1959) Use of dinitrosalicylic acid reagent for determination of reducing sugar. Analytical chemistry 31:426-428

45. Rastogi A, Banerjee R (2019) Production and characterization of cellulose from Leifsonia sp. Process Biochemistry 85:35-42. https://doi.org/10.1016/j.procbio.2019.06.008 
46. Xu A-R, Chen L, Guo X, et al (2018) Biodegradable lignocellulosic porous materials: Fabrication, characterization and its application in water processing. International Journal of Biological Macromolecules 115:846-852. https://doi.org/10.1016/j.ijbiomac.2018.04.133

47. Jiang F, Hsieh Y-L (2015) Cellulose nanocrystal isolation from tomato peels and assembled nanofibers. Carbohydrate Polymers 122:60-68. https://doi.org/10.1016/j.carbpol.2014.12.064

48. Belouadah Z, Toubal L, Belhaneche-Bensemra N, Ati A (2021) Characterization of ligno-cellulosic fiber extracted from Atriplex halimus L. plant. International Journal of Biological Macromolecules 168:806815. https://doi.org/10.1016/j.ijbiomac.2020.11.142

49. Moshi AAM, Ravindran D, Bharathi SRS, et al (2020) Characterization of a new cellulosic natural fiber extracted from the root of Ficus religiosa tree. International Journal of Biological Macromolecules 142:212-221. https://doi.org/10.1016/j.ijbiomac.2019.09.094

50. Alotaibi MD, Alshammari BA, Saba N, et al (2019) Characterization of natural fiber obtained from different parts of date palm tree (Phoenix dactylifera L.). International Journal of Biological Macromolecules 135:69-76. https://doi.org/10.1016/j.ijbiomac.2019.05.102

51. C.S. JC, George N, Narayanankutty SK (2016) Isolation and characterization of cellulose nanofibrils from arecanut husk fibre. Carbohydrate Polymers 142:158-166. https://doi.org/10.1016/j.carbpol.2016.01.015

52. Vijay R, Lenin Singaravelu D, Vinod A, et al (2019) Characterization of raw and alkali treated new natural cellulosic fibers from Tridax procumbens. International Journal of Biological Macromolecules 125:99_ 108. https://doi.org/10.1016/j.ijbiomac.2018.12.056

53. Segal L, Creely JJ, Martin AE, Conrad CM (1959) An Empirical Method for Estimating the Degree of Crystallinity of Native Cellulose Using the X-Ray Diffractometer. Textile Research Journal 29:786-794. https://doi.org/10.1177/004051755902901003

54. Jabihulla Shariff Md SCK (2020) Characterization of novel natural cellulosic fiber extracted from the stem of Cissus vitiginea plant. International Journal of Biological Macromolecules 161:1358-1370. https://doi.org/10.1016/j.ijbiomac.2020.07.230

55. Ganapathy T, Sathiskumar R, Senthamaraikannan P, et al (2019) Characterization of raw and alkali treated new natural cellulosic fibres extracted from the aerial roots of banyan tree. International Journal of Biological Macromolecules 138:573-581. https://doi.org/10.1016/j.ijbiomac.2019.07.136

\section{Figure captions}

Fig. 1. Particle size distribution of the shoot vine waste of all samples.

Fig. 2. ATR-FTIR spectra of shoot vine waste.

Fig. 3. X-ray diffraction patterns of shoot vines waste.

Fig. 4. TG-DSC analysis of the shoot vines waste

Fig. 5. Response surface plots showing the effects of concentration of TFA acid, Extraction time and Ratio (solid-liquid) on reducing sugar yield. 
Table 1. The variables and levels in statistical design for screening affecting sugar extraction yield.

\begin{tabular}{clcc}
\hline Variable code & \multicolumn{1}{c}{ Variables Name } & Low level (-1) & High level $(+1)$ \\
\hline$X_{1}$ & Agitation speed & $500 \mathrm{rpm}$ & $750 \mathrm{rpm}$ \\
$X_{2}$ & Concentration of TFA acid & $1 \%$ & $10 \%$ \\
$X_{3}$ & Temperature & $60{ }^{\circ} \mathrm{C}$ & $100^{\circ} \mathrm{C}$ \\
$X_{4}$ & (solid/liquid) Ratio & $1 \mathrm{~g} / 100 \mathrm{ml}$ & $5 \mathrm{~g} / 100 \mathrm{ml}$ \\
$X_{5}$ & Particle size of powders & $125 \mu \mathrm{m}$ & $500 \mu \mathrm{m}$ \\
$X_{6}$ & Extraction time & $20 \mathrm{~min}$ & $180 \mathrm{~min}$ \\
\hline
\end{tabular}

Table 2. The variables and levels in statistical design for optimization affecting sugar extraction yield.

\begin{tabular}{ccccc}
\hline $\begin{array}{c}\text { Variable } \\
\text { code }\end{array}$ & Variables Name & Low level (-1) & Middle level (0) & High level (+1) \\
\hline$X_{1}$ & Concentration of TFA acid & $1 \%$ & $5.5 \%$ & $10 \%$ \\
$X_{2}$ & Ratio (solid /liquid) & $1 \mathrm{~g} / 100 \mathrm{ml}$ & $3 \mathrm{~g} / 100 \mathrm{ml}$ & $5 \mathrm{~g} / 100 \mathrm{ml}$ \\
$X_{3}$ & Extraction time & $20 \mathrm{~min}$ & $100 \mathrm{~min}$ & $180 \mathrm{~min}$ \\
\hline
\end{tabular}

Table 3. Biomass composition of shoot vines waste.

\begin{tabular}{ccc} 
& Biomass & Content (\%) \\
\cline { 2 - 3 } & Moisture & $11.7 \pm 0.46$ \\
\hline Holocellulose (\%) & Alpha-cellulose & $43.38 \pm 0.60$ \\
$66.96 \% \pm 0.75$ & Hemicellulose & $23.58 \pm 0.67$ \\
\hline Extractive (\%) & Fat & $0.81 \pm 0.14$ \\
$3.67 \%$ & Total sugar & $0.56 \pm 0.11$ \\
& Extractive (hexane -ethanol) & $2.3 \pm 0.46$ \\
\hline XRF analysis & Calcium oxide & 61.5 \\
Minerals content or & Potassium oxide & 21.5 \\
Ash (\%) & Silica & 7.43 \\
\hline $.5 \% \pm 0.22$ & Phosphorus pentoxide & 5.80 \\
& Sulfur trioxide & 3.42 \\
\hline Crude protein & & $5.62 \% \pm 0.19$ \\
\hline Klason Lignin & & $21.22 \% \pm 0.71$ \\
\hline
\end{tabular}


Table 4. The Plackett-Burman design of the shoot vine waste and experimental values of response variables.

\begin{tabular}{cccccccc}
\hline \multirow{2}{*}{ Run } & \multicolumn{3}{c}{ Process parameters } & \multicolumn{2}{c}{$Y$} \\
\cline { 2 - 7 } & $\begin{array}{c}\text { Agitation speed } \\
(\mathrm{rpm})\end{array}$ & $\begin{array}{c}\text { Temperature } \\
\left({ }^{\circ} \mathrm{C}\right)\end{array}$ & $\begin{array}{c}\text { Time } \\
(\mathrm{min})\end{array}$ & $\begin{array}{c}\text { Concentration } \\
(\%)\end{array}$ & $\begin{array}{c}\text { Size } \\
(\mu \mathrm{m})\end{array}$ & $\begin{array}{c}\text { Ratio } \\
(\mathrm{g} / \mathrm{ml})\end{array}$ & $\begin{array}{c}\text { Sugar } \\
\text { Extraction } \\
(\%)\end{array}$ \\
\hline 1 & 100 & 180 & 1 & 125 & 1 & 0.1769 \\
2 & 750 & 60 & 180 & 1 & 500 & 5 & 0.1938 \\
3 & 500 & 100 & 20 & 1 & 500 & 1 & 0.0223 \\
4 & 500 & 100 & 20 & 10 & 500 & 5 & 0.4896 \\
5 & 500 & 60 & 180 & 1 & 125 & 5 & 0.1063 \\
6 & 500 & 60 & 180 & 10 & 500 & 1 & 0.2192 \\
7 & 750 & 60 & 20 & 1 & 500 & 1 & 0.0144 \\
8 & 750 & 60 & 20 & 10 & 125 & 5 & 0.2037 \\
9 & 750 & 100 & 20 & 1 & 125 & 5 & 0.3479 \\
10 & 750 & 60 & 20 & 10 & 125 & 1 & 0.0108 \\
11 & 500 & 100 & 180 & 10 & 125 & 1 & 0.2354 \\
12 & 500 & 100 & 180 & 10 & 500 & 5 & 1.0033 \\
\hline
\end{tabular}

Table 5. Regression analysis (ANOVA) of Plackett-Burman design experimental results on sugar extraction from shoot vine waste by acid extraction.

\begin{tabular}{ccccccc}
\hline Source & Sum of squares & DF & Mean squares & F-value & $P$-value & Significance \\
\hline Model & 0.7565 & 6 & 0.1261 & 8.4220 & 0.0168 & Significant \\
$X_{1}$ & 0.0686 & 1 & 0.0686 & 4.5804 & 0.0853 & Insignificant \\
$X_{2}$ & 0.1409 & 1 & 0.1409 & 9.4118 & 0.0279 & Significant \\
$X_{3}$ & 0.1943 & 1 & 0.1943 & 12.9817 & 0.0155 & Significant \\
$X_{4}$ & 0.2312 & 1 & 0.2312 & 15.4424 & 0.0111 & Significant \\
$X_{5}$ & 0.0618 & 1 & 0.0618 & 4.1316 & 0.0978 & Insignificant \\
$X_{6}$ & 0.0596 & 1 & 0.0596 & 3.9840 & 0.1025 & Insignificant \\
\hline Residual & 0.0748 & 5 & 0.0150 & & & \\
Cor Total & 0.8313 & 11 & & & & \\
\hline
\end{tabular}

Table 6. Estimated coefficient, calculated t-value, P-value and Std Error of Plackett-Burman experimental design.

\begin{tabular}{ccccc}
\hline Term & Coefficient & Std Error & T Ratio & Prob $>|t|$ \\
\hline Intercept & 0.4494 & 0.0578 & 7.7814 & 0.0006 \\
Agitation speed & 0.0756 & 0.0353 & 2.1402 & 0.0853 \\
TFA concentration & 0.1084 & 0.0353 & 3.0679 & 0.0279 \\
Temperature & 0.1273 & 0.0353 & 3.6030 & 0.0155 \\
(Solid/liquid) ratio & 0.3123 & 0.0795 & 3.9297 & 0.0111 \\
Particle size & 0.0479 & 0.0235 & 2.0326 & 0.0978 \\
Extraction time & 0.0705 & 0.0353 & 1.9960 & 0.1025 \\
\hline
\end{tabular}


Table 7. Box Behnken design of the shoot vine waste and experimental values of response variables.

\begin{tabular}{cccccc}
\hline $\begin{array}{c}\text { Exp } \\
\text { Order }\end{array}$ & \multicolumn{3}{c}{ Process parameters } & \multicolumn{3}{c}{ Sugar extraction $(Y)$} \\
& $\begin{array}{c}\text { Time } \\
(\mathrm{min})\end{array}$ & $\begin{array}{c}\text { Ratio } \\
(\mathrm{g} / \mathrm{ml})\end{array}$ & $\begin{array}{c}\text { Concentration } \\
(\%)\end{array}$ & $\begin{array}{c}\text { Experiment } \\
(\%)\end{array}$ & $\begin{array}{c}\text { Predicted } \\
(\%)\end{array}$ \\
\hline 1 & & & & 0.0993 & -0.0244 \\
2 & 100 & 1 & 10 & 0.7188 & 0.7188 \\
3 & 100 & 3 & 5.5 & 0.6970 & 0.7208 \\
4 & 100 & 5 & 1 & 0.5092 & 0.3122 \\
5 & 180 & 1 & 5.5 & 0.7567 & 0.8575 \\
6 & 180 & 3 & 10 & 0.7081 & 0.7942 \\
7 & 180 & 3 & 1 & 0.7188 & 0.7188 \\
8 & 100 & 3 & 5.5 & 2.5321 & 0.1222 \\
9 & 180 & 5 & 5.5 & 0.3852 & 1.1110 \\
10 & 20 & 3 & 10 & 0.9219 & 0.0323 \\
11 & 100 & 5 & 10 & 0.0531 & 0.6624 \\
12 & 20 & 3 & 1 & 0.6654 & 0.5520 \\
13 & 20 & 5 & 5.5 & 0.4420 & -0.0643 \\
14 & 20 & 1 & 5.5 & 0.0848 & 0.7188 \\
15 & 100 & 1 & 1 & 0.7188 & \\
\hline
\end{tabular}

Table 8. Parameter estimates for linear, quadratic and interaction effects of the variable on reducing sugar yield.

\begin{tabular}{ccccc}
\hline Term & Coefficient & Std Error & T Ratio & Prob $>|t|$ \\
\hline Intercept & 0.7188 & 0.1119 & 6.4256 & 0.0014 \\
$X_{1}$ & 0.0775 & 0.0685 & 1.1315 & 0.3092 \\
$X_{2}$ & 0.4601 & 0.0685 & 6.7167 & 0.0011 \\
$X_{3}$ & 0.3701 & 0.0685 & 5.4019 & 0.0029 \\
$X_{1} * X_{2}$ & 0.0526 & 0.0969 & 0.5429 & 0.6105 \\
$X_{1} * X_{3}$ & -0.0709 & 0.0969 & -0.7315 & 0.4973 \\
$X_{2} * X_{3}$ & 0.4499 & 0.0969 & 4.6436 & 0.0056 \\
$X_{1}{ }^{2}$ & -0.4147 & 0.1008 & -4.1128 & 0.0092 \\
$X_{2} X_{3}^{2}$ & 0.1467 & 0.1008 & 1.4545 & 0.2056 \\
\end{tabular}

Table 9. ANOVA of Box Behnken design experimental results on sugar extraction from shoot vine waste by acid extraction.

\begin{tabular}{|c|c|c|c|c|c|c|c|}
\hline & Source & $\begin{array}{c}\text { Sum of } \\
\text { squares }\end{array}$ & $D F$ & Mean squares & F-value & P-value & Significance \\
\hline \multirow{4}{*}{ Linear } & Model & 4.5674 & 09 & 0.5075 & 13.5177 & 0.0052 & \multirow[t]{2}{*}{ Significant } \\
\hline & $X_{1}$ & 0.0481 & 01 & 0.0418 & 1.2803 & 0.3092 & \\
\hline & $X_{2}$ & 1.6937 & 01 & 1.6937 & 45.1145 & 0.0011 & Significant \\
\hline & $X_{3}$ & 1.0955 & 01 & 1.0955 & 29.1810 & 0.0029 & Significant \\
\hline \multirow{3}{*}{ Interaction } & $X_{1} * X_{2}$ & 0.0111 & 01 & 0.0111 & 0.2948 & 0.6105 & \multirow{7}{*}{$\begin{array}{l}\text { Significant } \\
\text { Significant }\end{array}$} \\
\hline & $X_{1} * X_{3}$ & 0.0201 & 01 & 0.0201 & 0.5351 & 0.4973 & \\
\hline & $X_{2} * X_{3}$ & 0.8095 & 01 & 0.8095 & 21.5633 & 0.0056 & \\
\hline \multirow{7}{*}{ Quadratic } & $X_{1}^{2}$ & 0.6350 & 01 & 0.6350 & 16.9147 & 0.0092 & \\
\hline & $X_{2}{ }^{2}$ & 0.0794 & 01 & 0.0794 & 2.1156 & 0.2056 & \\
\hline & $X_{3}^{2}$ & 0.1088 & 01 & 0.1088 & 2.8989 & 0.1494 & \\
\hline & Residual & 0.1877 & 05 & 0.0375 & & & \\
\hline & Lack of Fit & 0.1877 & 03 & 0.0626 & \multirow[t]{3}{*}{. } & & \\
\hline & Pure Error & 0.0000 & 02 & 0.0000 & & & \\
\hline & Cor Total & 4.7551 & 14 & & & & \\
\hline
\end{tabular}




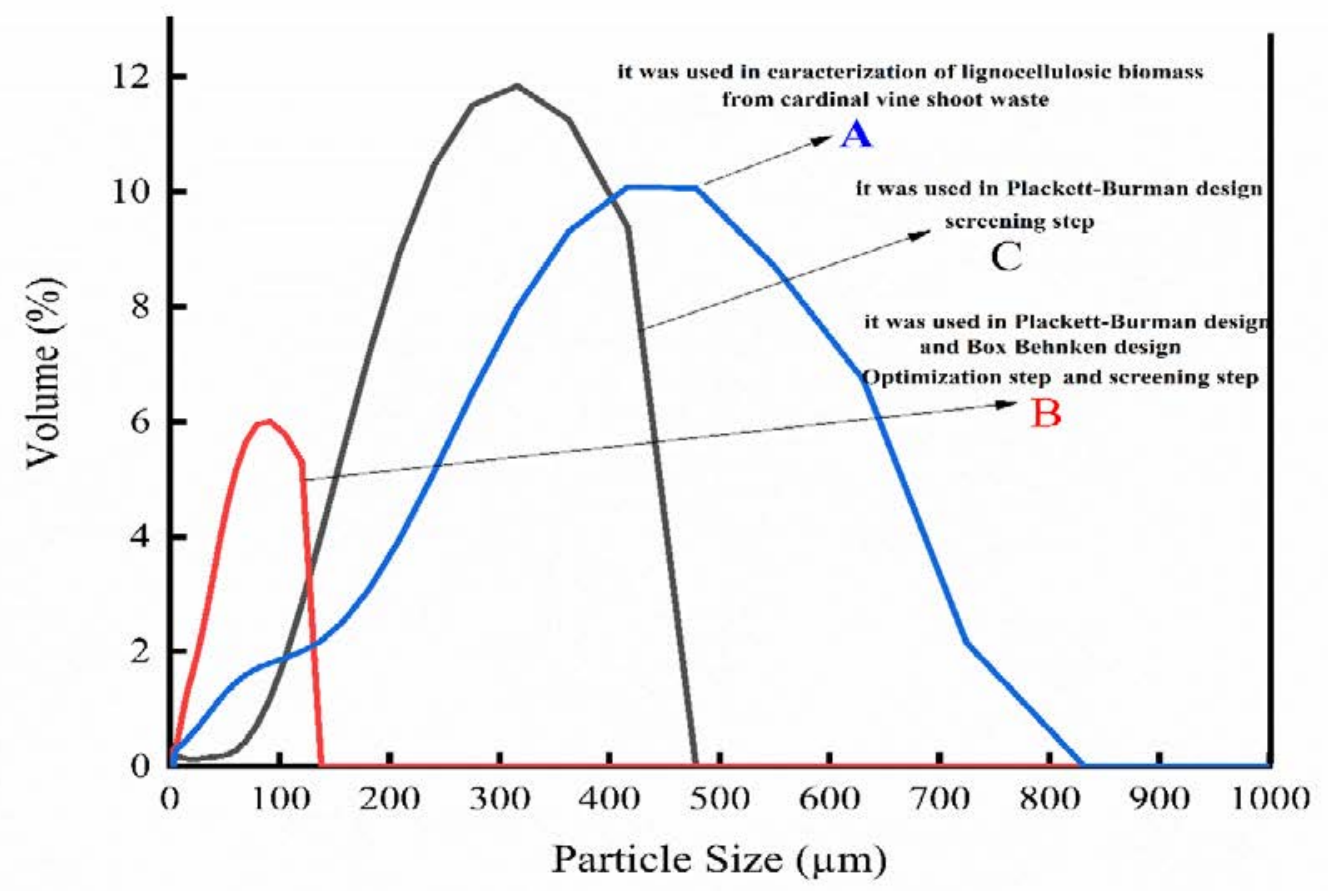

Fig. 1. Particle size distribution of shoot vine waste of all samples. 


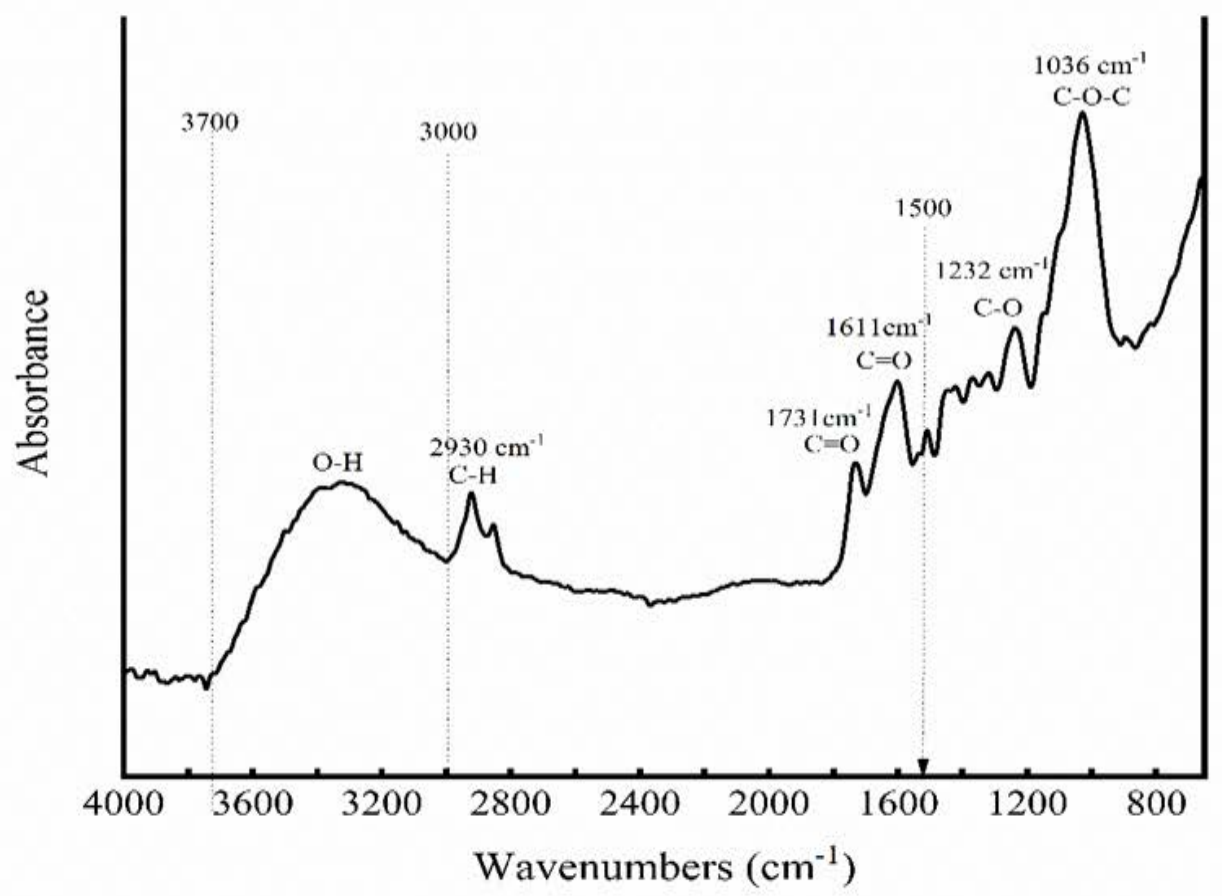

Fig. 2. ATR-FTIR spectra of shoot vine waste. 


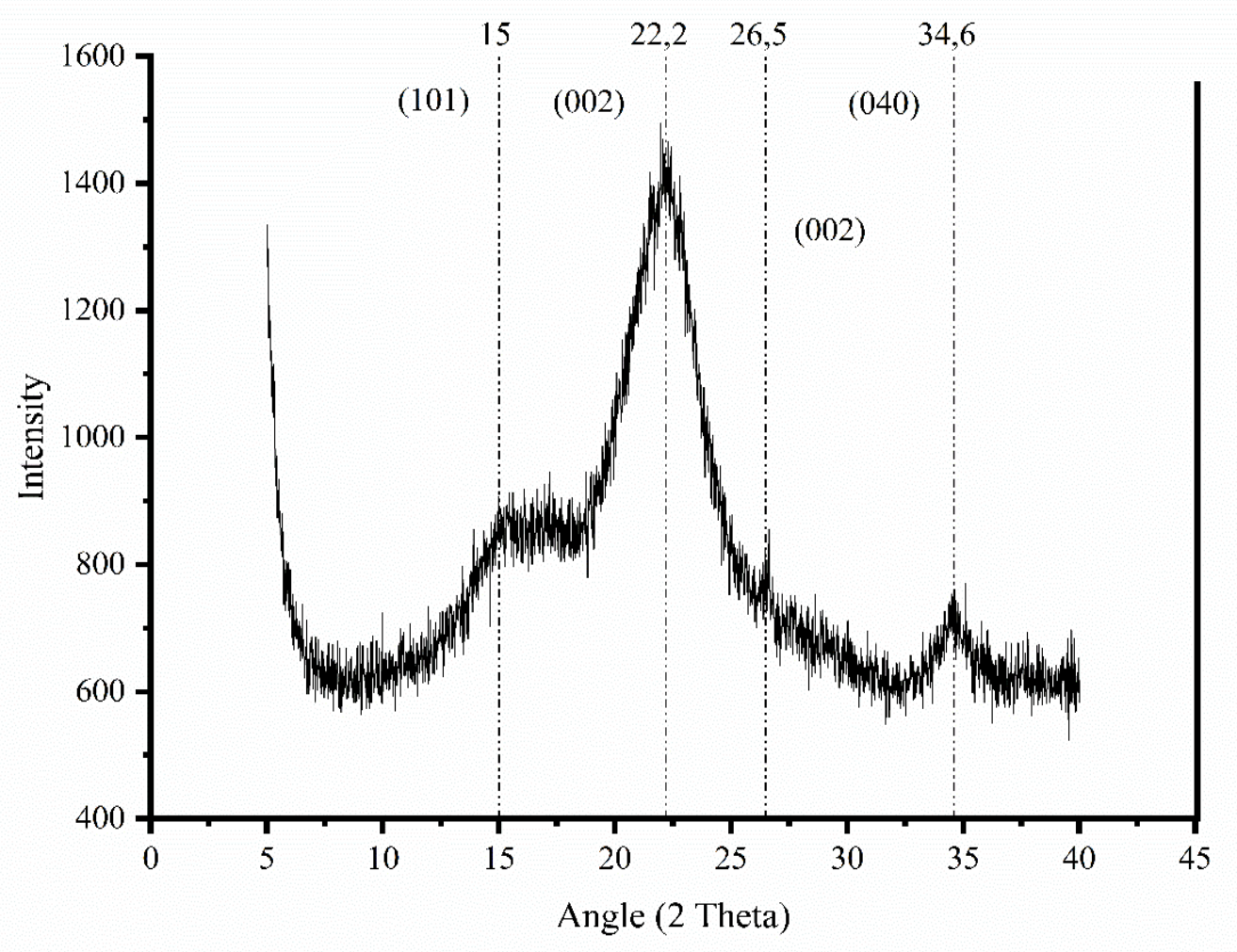

Fig. 3. X-ray diffraction patterns of shoot vines waste. 
Thermogravimetric (\%)

Differential scanning calorimetry $(\mathrm{mW} / \mathrm{mg})$

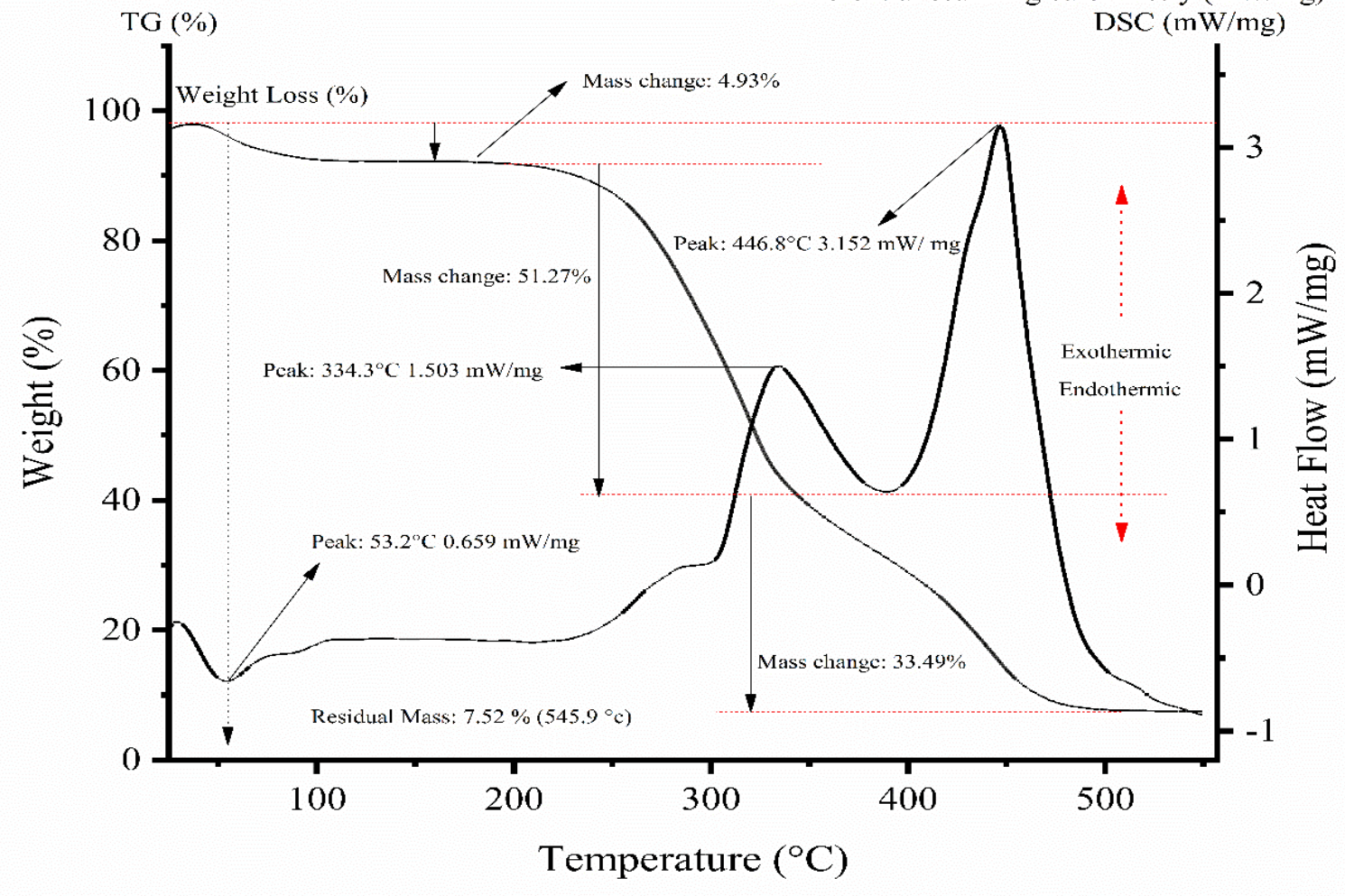

Fig. 4. TG-DSC analysis of the shoot vines waste. 


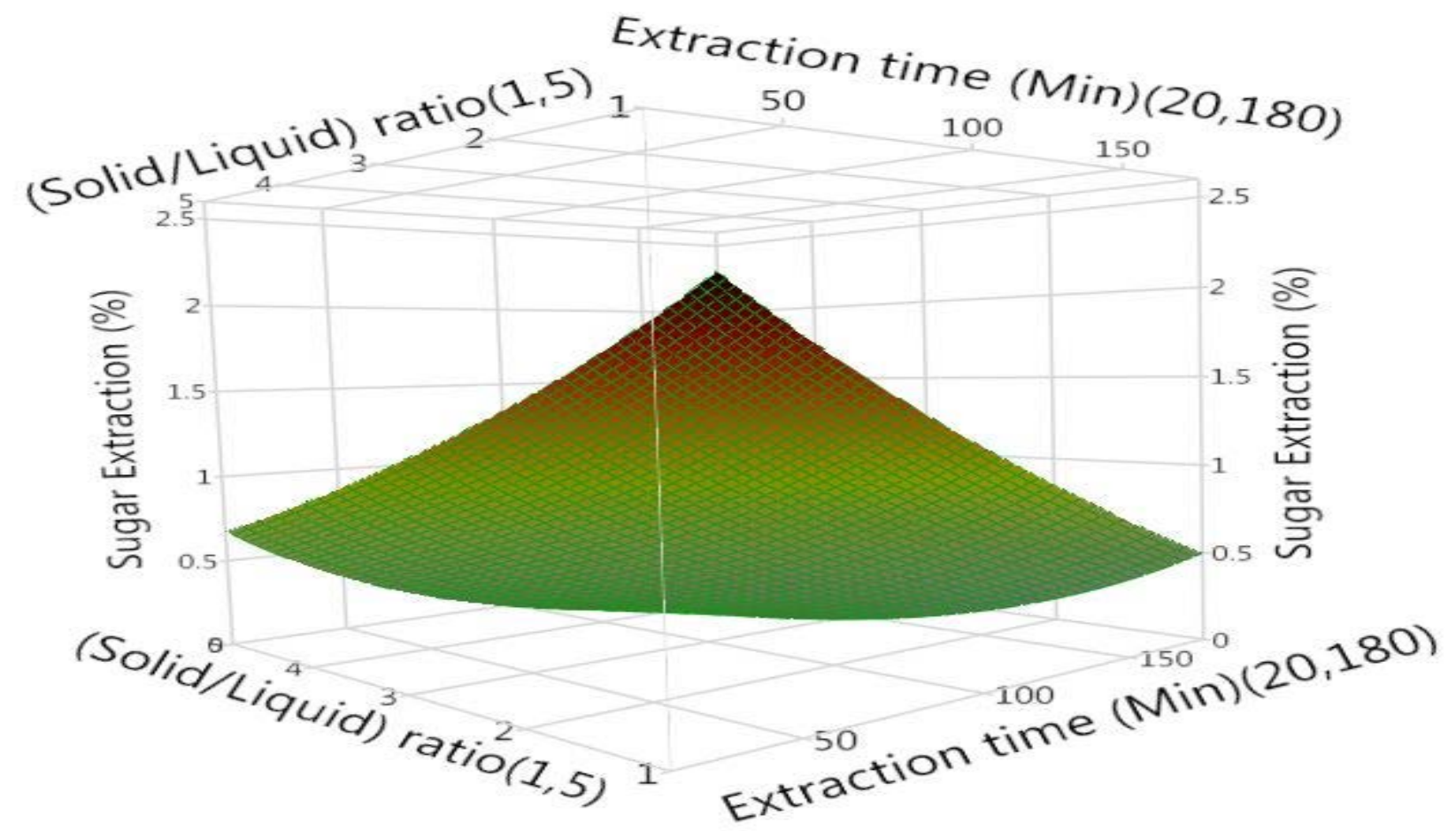

Fig (5a). 3D response plot showing interactions between extraction time and (solid/liquid) ratio.

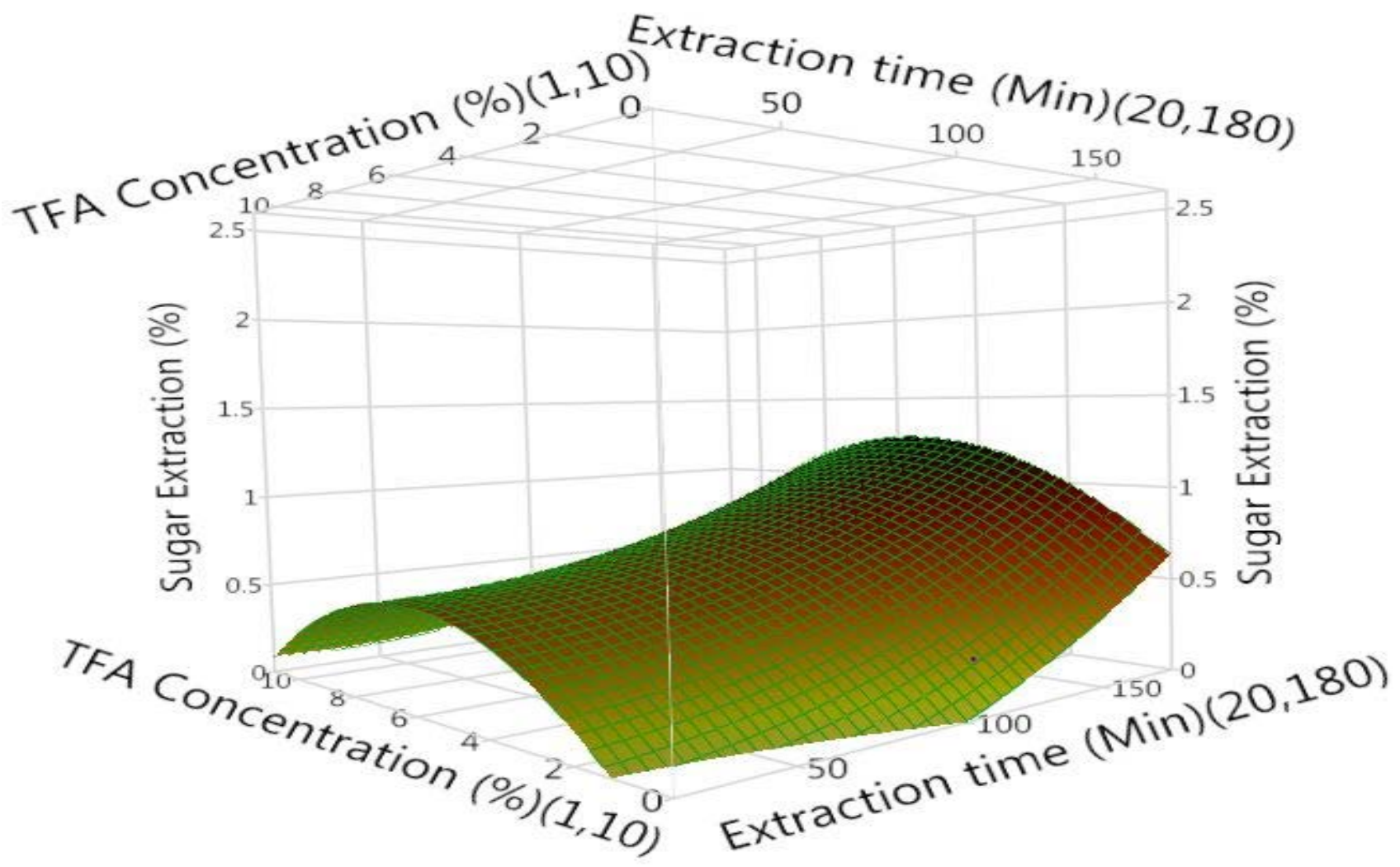

Fig.(5b). 3D response plot showing interactions between TFA concentration and extraction time. 


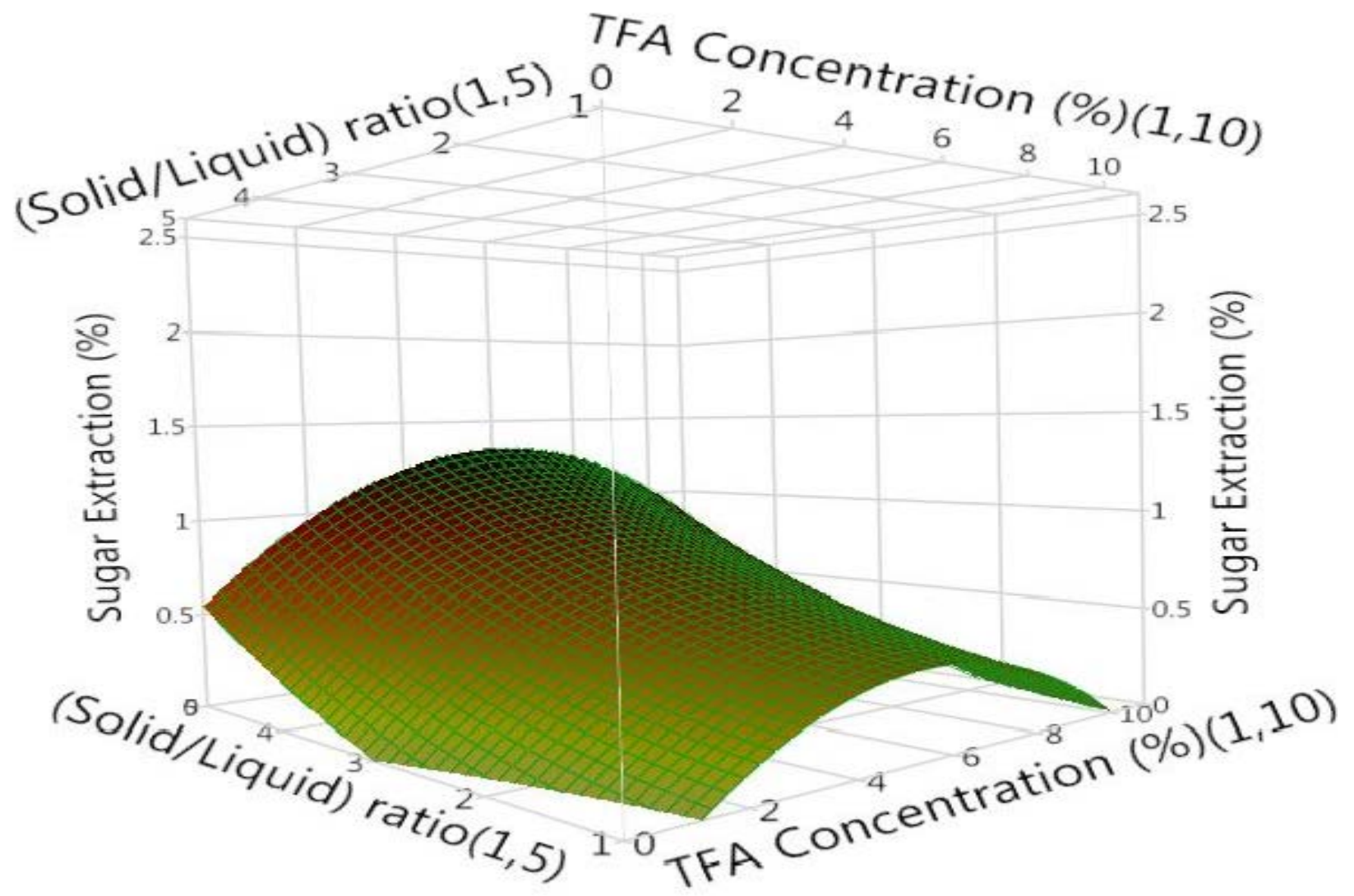

Fig.(5c). 3D response plot showing interactions between TFA concentration and (solid/liquid) ratio.

Fig. 5. Response surface plots showing the effects of concentration of TFA acid, extraction time and ratio (solid-liquid) on reducing sugar. 